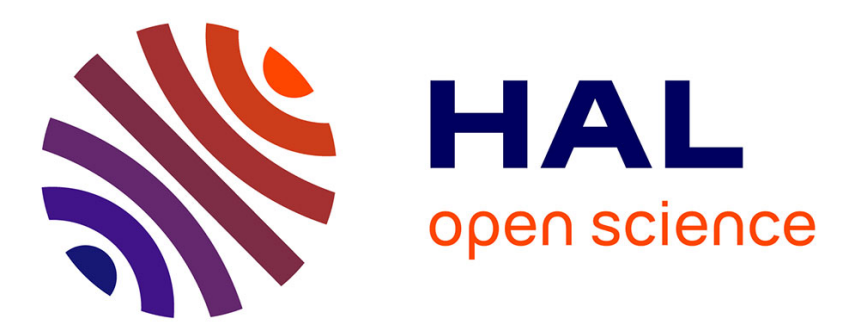

\title{
Editorial for "Clinical Quantification of Myocardial Perfusion With Vasodilation Using Arterial Spin Labeling at $1.5 \mathrm{~T} "$
}

\author{
F. Kober
}

\section{- To cite this version:}

F. Kober. Editorial for "Clinical Quantification of Myocardial Perfusion With Vasodilation Using Arterial Spin Labeling at 1.5T". Journal of Magnetic Resonance Imaging, 2021, 10.1002/jmri.27422 . hal-03008874

\section{HAL Id: hal-03008874 \\ https://hal-amu.archives-ouvertes.fr/hal-03008874}

Submitted on 17 Nov 2020

HAL is a multi-disciplinary open access archive for the deposit and dissemination of scientific research documents, whether they are published or not. The documents may come from teaching and research institutions in France or abroad, or from public or private research centers.
L'archive ouverte pluridisciplinaire HAL, est destinée au dépôt et à la diffusion de documents scientifiques de niveau recherche, publiés ou non, émanant des établissements d'enseignement et de recherche français ou étrangers, des laboratoires publics ou privés. 


\title{
Editorial for "Clinical Quantification of Myocardial Perfusion with Vasodilation using Arterial Spin Labeling at 1.5T"
}

\author{
Frank Kober, Ph.D. ${ }^{1 *}$ \\ ${ }^{1}$ Aix-Marseille Univ, CNRS, CRMBM, Faculté de Médecine, 27 Bd J Moulin, 13005 Marseille, France
}

\author{
* Corresponding Author \\ Frank Kober, Ph.D. \\ Aix-Marseille Université \\ Centre de Résonance Magnétique Biologique et Médicale \\ (CRMBM) \\ Faculté de Médecine \\ 13005 Marseille, France \\ email: frank.kober@univ-amu.fr
}

Ever since Arterial Spin Labeling MRI was shown feasible in the human brain for quantitative tissue perfusion mapping without contrast agents, there have been attempts to achieve the same in the heart with similar methods. The motivation for quantifying myocardial blood flow (MBF) is particularly evident, because the perfusion changes measured under different conditions directly give insight into the status of the capillary system's health. ASL is attractive in the heart, because quantitative first-pass MRI rest-stress comparisons necessitate two or more dynamic contrastinjection sequences, depending on the chosen approach (dual-contrast, dual-sequence). Whereas consensus on first-pass post-processing has become much clearer in the recent years, a push-button MBF quantification method is still not available as part of clinical systems at this time. Finally, driven by an over-proportional number of subjects requiring special attention regarding contrast agents, there is a general tendency in cardiac MRI towards other contrast-agent free cardiac MR approaches via "native" tissue parameter mapping methods, such as quantitative T1 mapping.

Expectations from cardiac ASL were high at the beginning, because at the first glance its sensitivity should be at least equal to that in the brain, given the similar or higher tissue blood flow. However, the efficiency constraints in cardiac MR are easily underestimated, and already the first studies in the late 90's showed that it would take more time to get there in the heart $(1,2)$. Both spatial and temporal resolution requirements are high, the former because of large amounts of ventricular blood and the latter because of motion. Both requirements are somewhat unsatisfied because the frame duration is limited by cardiac motion and the acquisition duration by that of a breath-hold. Analyses of physiological noise and use of higher-field systems in conjunction with signalefficient and well-resolved bSSFP sequences have led to convincing results in patients with coronary artery disease a decade later (JACC Cardiovasc. Imaging 2011), and various following improvements for improving sensitivity and handling of motion were undertaken (3-5).

\section{References}

1. Poncelet BP, Koelling TM, Schmidt CJ, et al. Measurement of human myocardial perfusion by double-gated flow alternating inversion recovery EPI. Magn Reson Med 1999;41:510-9.
In this JMRI issue, Aramendía-Vidaurreta et al. report MBF measurements using ASL in patients with suspected coronary artery disease (6). They employed a single-gated cardiac Flow-Alternating Inversion Recovery (FAIR) bSSFP ASL method, which was already successfully used in earlier studies, in particular in the pioneering work done by Zun et al. (7) (29 patients), but also by others. While the earlier studies used a very similar approach under breath-hold, one addition of the current one lies in the fact that it was done in a clinical setting on a standard $1.5 \mathrm{~T}$ system with the subjects under "controlled breathing", in an attempt to prolong continuous scan time. Images that were affected by motion were excluded by visual inspection during post-processing. The ASL acquisitions were done within a routine first-pass rest/regadenoson stress protocol carried out on patients with suspected coronary artery disease. MBF and perfusion reserve (MPR) obtained from ASL were compared with the semi-quantitative first-pass perfusion parameters. They also confronted ASL MBF to the semiquantitative perfusion index. One important finding was that the correlations between ASL and first-pass were significant for both parameters MPR and MBF, although particularly the latter was only moderate. As another interesting result, ASL measured much higher perfusion reserve values than first-pass. From this and the fact that the ASL signal is directly proportional to tissue blood flow, it may be speculated that ASL could be even better suited for detecting hyperemic changes than first-pass. Good performance of ASL at high blood flow is well known and in fact one of the reasons for its success in small animal studies $(8,9)$.

The authors open towards future improvements of postprocessing and better handling of sequence timing with a number of improvements done by other groups. For instance, the single-gating FAIR sequence they used predicts the cardiac phase over two cycles and makes the approach vulnerable to variations in heart rate. Doublegating was shown advantageous (5) in that regard. While the controlled (instructed) breathing approach may be considered as a complication for technologists and patients, it is certainly much less of a constraint than two long breath-holds during bolus injections.

Given the small number of patients $(\mathrm{N}=18)$ studied it is, yet again, impossible to conclude that ASL may one day replace $1^{\text {st }}$ pass measurements for stress studies, but the expectation that ASL will play a role in cardiac MRI examinations clearly emerges strengthened.

2. Wacker CM, Bock M, Hartlep AW, et al. Changes in myocardial oxygenation and perfusion under pharmacological stress with dipyridamole: assessment using $\mathrm{T}^{*} 2$ and $\mathrm{T} 1$ measurements. Magn. Reson. Med. Off. J. Soc. Magn. Reson. Med. Soc. Magn. Reson. Med. 1999;41:686-695. 
3. Do HP, Jao TR, Nayak KS. Myocardial arterial spin labeling perfusion imaging with improved sensitivity. J. Cardiovasc. Magn. Reson. 2014;16:15 doi: 10.1186/1532-429X-16-15.

4. Capron T, Troalen T, Robert B, Jacquier A, Bernard M, Kober F. Myocardial perfusion assessment in humans using steadypulsed arterial spin labeling. Magn. Reson. Med. 2015;74:990 998 doi: $10.1002 / \mathrm{mrm} .25479$.

5. Do HP, Yoon AJ, Fong MW, Saremi F, Barr ML, Nayak KS. Double-gated myocardial ASL perfusion imaging is robust to heart rate variation. Magn. Reson. Med. 2017;77:1975-1980 doi: 10.1002/mrm.26282.

6. Aramendía-Vidaurreta V, Echeverría-Chasco R, Vidorreta M, Bastarrika G, Fernández-Seara MA. Quantification of Myocardial Perfusion With Vasodilation Using Arterial Spin Labeling at 1.5T. J. Magn. Reson. Imaging JMRI 2020 doi: 10.1002/jmri.27396.
7. Zun Z, Varadarajan P, Pai RG, Wong EC, Nayak KS. Arterial Spin Labeled CMR Detects Clinically Relevant Increase in Myocardial Blood Flow With Vasodilation. JACC Cardiovasc. Imaging 2011;4:1253-1261 doi: 10.1016/j.jcmg.2011.06.023.

8. Naresh NK, Chen X, Moran E, Tian Y, French BA, Epstein FH. Repeatability and variability of myocardial perfusion imaging techniques in mice: Comparison of arterial spin labeling and first-pass contrast-enhanced MRI. Magn. Reson. Med. 2015 doi: 10.1002/mrm.25769.

9. Troalen T, Capron T, Bernard M, Kober F. In vivo characterization of rodent cyclic myocardial perfusion variation at rest and during adenosine-induced stress using cine-ASL cardiovascular magnetic resonance. J. Cardiovasc. Magn. Reson. 2014;16:18 doi: 10.1186/1532-429X-16-18. 